REGARDS

SUR L'ECONOMIE ALLEMANDE

BULLETIN ECONOMIQUE DU CIRAC
Regards sur l'économie allemande

Bulletin économique du CIRAC

$82 \mid 2007$

Varia

\title{
Système bancaire
}

DIW, Zukunft des deutschen Bankensektors

\section{OpenEdition}

\section{Journals}

Édition électronique

URL : http://journals.openedition.org/rea/437

DOI : $10.4000 /$ rea.437

ISBN : 978-2-8218-0860-7

ISSN : 1965-0787

\section{Éditeur}

CIRAC

\section{Édition imprimée}

Date de publication : 1 juillet 2007

ISSN : 1156-8992

\section{Référence électronique}

"Système bancaire ", Regards sur l'économie allemande [En ligne], 82 | juillet 2007, document 6, mis en ligne le 23 avril 2008, consulté le 22 septembre 2020. URL : http://journals.openedition.org/rea/437 : DOI : https://doi.org/10.4000/rea.437

Ce document a été généré automatiquement le 22 septembre 2020

(c) CIRAC 


\title{
Système bancaire
}

\author{
DIW, Zukunft des deutschen Bankensektors
}

\section{RÉFÉRENCE}

DIW, Zukunft des deutschen Bankensektors, Coll. Vierteljahrshefte zur Wirtschaftsforschung, $n^{\circ}$ 4/2006, Duncker \& Humblot, Berlin, 2006, 170 p.

1 L'institut DIW de Berlin présente là un prisme d'analyses sur les restructurations en cours et l'avenir du système bancaire allemand. L'interrogation au cœur de toutes les contributions théoriques et pratiques rassemblées dans cette publication est celle-ci : comment réformer le système à trois piliers (banques publiques, privées et coopératives) qui s'était structuré au sortir de la guerre pour répondre aux besoins d'une économie en reconstruction afin de l'adapter aux mutations mondiales de la finance et lui rendre sa compétitivité ? (ib) 